\title{
Strengthening Character Through Learning Of BAM Of Minang Language For Elementary School Students
}

\author{
Aldora Pratama ${ }^{1)}$, Erika Sari ${ }^{2)}$ \\ Universitas Nahdlatul Ulama, Sumatera Barat, Indonesia ${ }^{1,2)}$ \\ aldorapratama@univpgri-palembang.ac.id ${ }^{1)}$, erika.sari4455@gmail.com ${ }^{2)}$
}

\begin{abstract}
Essential education is to develop a whole person that is a good and characterful human being. The developed character values already exist in Minangkabau culture and customs. The customary philosophy of basandi syarak, the basandi syarak is the basis for the formation of character in culture and customs. Minang language is a form of local wisdom that must be continuously preserved and used in BAM local content learning activities. The Minang language is a communication tool in teaching traditional and cultural values in BAM learning. This study aims to determine the level of student understanding and reinforcement of character by teaching BAM in the Minangkabau language. The research method used is descriptive qualitative method. Where the approach in this study is carried out intensively, in depth, in detail, and comprehensive when PBM subjects natural cultural minangkabau. Data collection techniques in this study were interviews (interviews), observation, and documentation. Based on the results of research conducted shows that by teaching local content BAM in the Minang language is able to strengthen the character of students, Minang language as the mother tongue is easier to understand and comprehend by students, especially those related to expressions, rhymes and proverbs as well as the implementation of politeness as individuals in the family and society.
\end{abstract}

Keywords: Character Education, Minangkabau Natural Culture, Culture and Customs

\begin{abstract}
Abstrak. Pendidikan esensinya adalah membangun manusia seutuhnya yaitu manusia yang baik dan berkarakter, Nilai karakter yang dikembangkan telah ada dalam budaya dan adat istiadat Minangkabau. Falsafah adat basandi syarak, syarak basandi kitabulah menjadi dasar pembentukan karakter pada budaya dan adat istiadat. Bahasa minang merupakan salah satu bentuk kearifan lokal harus terus dilestarikan dan dipergunakan dalam kegiatan pembelajaran muatan lokal BAM. Bahasa Minang menjadi alat komunikasi dalam mengajarkan nilai nilai adat dan budaya pada pembelajaran BAM. Penelitian ini bertujuan untuk mengetahui tingkat pemahaman siswa serta penguatan karakter dengan mengajarkan BAM berbahasa Minangkabau. Metode penelitian yang digunakan ini adalah metode kualitatif deskriptif. Dimana pendekatan dalam penelitian ini dilakukan secara intensif, mendalam, mendetail, dan komperhensif pada saat PBM mata pelajaran budaya alam minangkabau. Teknik pengumpulan data dalam penelitian ini adalah wawancara (interview), observasi, dan dokumentasi. Berdasarkan hasil penelitian yang dilakukan menunjukkan bahwa dengan mengajarkan muatan lokal BAM dalam bahasa Minang mampu memperkuat karakter siswa, Bahasa Minang sebagai bahasa ibu lebih mudah difahami dan dimengerti oleh siswa terutama yang berkaitan dengan ungkapan, pantun dan pepatah petitih serta implementasi adab dan sopan santun sebagai individu dalam keluarga dan masyarakat.
\end{abstract}

Kata Kunci: Pendidikan Karakter, Budaya Alam Minangkabau, budaya dan adat istiadat 


\section{INTRODUCTION}

Character education is one of the goals of national education. Character is memorization and verbal knowledge, but the character is the education of a student's behaviour, attitude, and emotional intelligence. As Martin Luther King said "Intelligence plus character, that is the goal of true education" means "characterized intelligence is the ultimate goal of true education". Examining this expression means that the purpose of education is to shape the character of students. This is in line with the mandate of the National Education Law, which is to form Indonesian people who are intelligent and have personality or character to give birth to a generation that grows and develops with characters that breathe the noble values of the nation and religion. Character education can be interpreted as values, moral character education, a character which aims to develop students' abilities to make bad decisions, maintain goodness, spread goodness in everyday life with all their hearts (Salahudin, 2013).

Indonesia is a country that is large in culture (Hilden Gart, in Marnelli T.M, 2017: 150). The ancestors of the Indonesian people have passed down the noble values of culture from generation to generation in the form of culture and customs as well as other local wisdom. The life of the Indonesian people is full of cultural patterns, traditions, values, and norms. Culture is the result of the human mind that grows and develops in the life of Indonesian society. Culture cannot be separated from the character of a nation. The strong currents of globalization, modernization and strict puritanism can result in the erosion of a sense of love for local culture. Culture and customs are marginalized by foreign cultures, eliminated in their own country, and even forgotten by the next generation. Many of us find young people who prefer a westernized lifestyle, like foreign cultures so that their love for local culture begins to decrease. This phenomenon continues to grow among young people and students. Reviving local wisdom is very important to foster a love for national culture. One of the lessons that introduce the local wisdom and culture of West Sumatra is the Minangkabau Natural Culture (BAM) subject.

Local content of Minangkabau Natural Culture is one of the subjects that aims to prepare students to have insight into their environment, attitudes and behaviour and are willing to preserve and develop natural resources, social quality, and culture that support national and local development (Haromain, 2009). Through BAM learning students are equipped with knowledge about culture, customs, values and norms that are owned by the Minangkabau community and must be preserved. Character development which includes the values of human behaviour related to God Almighty, oneself, fellow human beings, environment and nationality 
which is manifested in thoughts, attitudes, feelings, words, and actions based on religious norms, laws, etiquette, culture and customs can be obtained through BAM learning.

Language is a reflection of a nation, the use of regional languages is one way to preserve local culture and traditions in students. Students must be equipped with local characters to be able to compete and not be easily influenced by globalization. The philosophy of life for the Minangkabau community, Alam Takambang Becomes a Guru, where this philosophy has developed into local culture and traditions that utilize and manage nature well. The form of implementation in everyday life can be seen from the way the Minangkabau people interact in developing traditional and cultural values in the form of behaviour and attitudes. The function of language as a unifying tool becomes a bridge for teachers in conveying the values of local wisdom to students. Because it is a legacy of our ancestors. In the world of education, local wisdom is embodied in local content subjects. According to the Ministry of Education and Culture (1989) states that local content is not only intended to maintain the preservation of regional culture, but also as an effort to renew or modernize by the development of modern science and technology. Local content is regulated in law number 2 of 1989 concerning the national education system, article 38 paragraph 1, namely the implementation of educational activities in educational units based on a nationally applicable curriculum and adapted to the circumstances and needs of the environment and the characteristics of the education unit concerned. This provision is emphasized by Ministerial Regulation No. 28 of 1990 concerning Basic Education Article 14 which reads: Basic education units can add subjects according to environmental conditions and the characteristics of the education unit concerned without reducing the national curriculum. This is the basis for the implementation of local content subjects.

Minangkabau Natural Culture is a local content in West Sumatra which is determined by decree No.011. 08.C.1994 dated February 1, 1994 by the Head of the Regional Office of the Ministry of Education and Culture of West Sumatra Province regarding local content at the elementary and junior high levels. Furthermore, the Instruction of the Governor of West Sumatra Province No. 14 of 1991 was emphasized. Regarding the local content of Minang Kabau Natural Culture (BAM), Read and write the Koran, Read and write Arabic Malay. In several schools in the city of Padang the local content of BAM has become a compulsory subject for students. In line with the implementation of the 2013 curriculum, BAM subjects are no longer independent subjects but are included in the content of Arts, Culture and Crafts, however, the existence of BAM subjects must be maintained as the only learning that introduces Minangkabau culture 
and customs to students at all levels. level of education. The use of language in delivering learning materials is very influential on the level of students' understanding of the learning objectives themselves. Minang language as the mother tongue is a means of communication in the daily lives of people in West Sumatra. The strength of the Minang language is one aspect of strengthening the preservation of regional culture.

Province of West Sumatra has a regional language known as the Minang language. The Minangkabau language or Baso Minang is one of the branches of Austronesian languages spoken especially in the West Sumatra region, the Minang language has four varieties of languages that influence and greatly the situation and conditions when the language will be used (Agustina, 2005) The four varieties of language are:

1. Variety of Traditional Languages. The use of various traditional languages is often found in traditional activities such as proverbs, traditional poem, pasambahan panghulu speeches, ninik mamak and traditional leaders. For example, “...di awal kato nan sapatah, menjadi ujuik jo makasuik, nan sarapak papeknyolah. Beliau nan hadir di ateh rumah nanko.

2. Variety of Surau Languages, In the past, the surau was a place to gain knowledge for the Minangkabau people, the existence of a surau was not only a place of worship but also to study traditional values and customs, the ulama in their religious activities used language and words that contained advice, religious teachings that influenced by absorption elements in Arabic. For example: “...sesuatu barang, nan kito tamui secaro indak sengajo, itu hukumnyo dalam islam adalah subhat. Artinyo labiah dakek kepado haram dari halalnyo. Andaikato suatu saat kito menemukan urang nan punyo barang tersebut, heloklah kito batarus terang kepadonyo, mintak ke ridhoan urang tasabut, Isnya Allah, Tuhan akan mengampuni doso kito...

3. Variety of Parewa Language,This variety of Parewa language is widely used by young people in communicating with each other. Usually, the language is a bit harsh, a little dirty, contains satire. Example: “...manga ang duduak di situ?" "barang sia nan ang cilok tu, angku lai, ndak tapikia sansai urang tuo manggadangkan ang!"

4. Variety of Ordinary Languages, namely the language used by people in communicating in everyday life. Example: "Pailah singah karumah mamak tu yuang?, di caliak caliak juolah mamak tu.

These four varieties of language show that the use of the Minang language is well structured in place and time. As a communication tool, the use of Minang language is very well used in conveying traditional and cultural values in schools. This should receive more serious attention, 
considering the development of the Minang youth generation today is far from the Minangkabau cultural norms. The use of Minang language in delivering BAM material at school is expected to be an attraction for students in studying material related to culture and customs and be able to strengthen the development of student character.

The provision of local character values of Minangkabau culture to students can be extracted from the culture and customs and traditions that exist around the community. These local values are very close to the community. Besides being very close, exploring contextual local values indirectly helps maintain and preserve these cultures and traditions. The cultural diversity that exists grows and develops. However, not all of this diversity has been explored and not all of them can be connected in the world of education.

\section{RESEARCH METHODS}

This research used qualitative research with descriptive method. This type of research used was descriptive quantitative research, which was one type of research that aimed at describing systematically, factually, and accurately about the facts and characteristics of certain populations, or try to describe phenomena in detail. In descriptive quantitative research focused on solving problems that exist in the present or problems of actual and meaningful events. (Muri, 2014). Qualitative research is research that aims to understand what phenomena are experienced by research subjects. In this case, the use of Minang language in BAM learning was to strengthen the character of students. This research was conducted in two elementary schools, namely SD Pertiwi 3 Padang, Padang Timur subdistrict and SDN 10 Sungai Sapih, Kuranji sub district for fifth-grade students. Upper-middle-class economy and another school located on the outskirts of the city of Padang which was still very thick with its traditional culture and the students were mostly native people of the Kuranji subdistrict. Research data collection techniques obtained through observation, interviews, documentation. To collect data obtained from primary data and secondary data. Primary data was obtained through observations and field interviews with students and teachers who taught BAM in class $\mathrm{V}$, while secondary data was obtained through literature review. Another instrument used was the camera to avoid data loss. In addition, researchers also established good communication with the school to avoid suspicions that could interfere with the interview process (Bungin, 2007). The data analysis technique used was interactive analysis technique or qualitative analysis which was a cyclical process that moved from three main components of data reduction, data presentation and drawing conclusions and verification (Miles and Hubermant 1984, in Sutopo, 2006). 


\section{DISCUSSION}

In this section, the research result is explained into several sub-sections regarding strengthening student character through Minang language BAM learning for elementary school students which includes character values in Minangkabau traditional culture, Minang language functions in BAM learning, implementation of BAM learning in elementary schools.

\section{Character values in Minangkabau culture, customs and traditions.}

In 2009, the Ministry of Education and Culture began to impose character education on students at all levels of education in Indonesia. Character comes from the Greek language which means "To Mark" which marks or focuses on how to apply the value of goodness in the form of actions and behaviour so that people who behave badly like lying, tyrants are said to have bad character, while people who always do good are said to have good character. The Ministry of National Education language centre defines character as innate heart, soul, personality, character, temperament, character. Character refers to a series of attitudes, behaviour, motivation, and skills (Musfiroh, 2008). The formation of national character is rooted in cultural values and customs. The character of the Indonesian nation is a character that is based on Pancasila which contains elements of personality which are the identity of the nation (Budimansyah,
29). In line with this concept, the Minangkabau community is a picture of a community group that upholds the values of the nation's character. The life of the Minangkabau community, which is based on the traditional philosophy of Basandi Syarak, Syarak Basand Kitabullah, has become the life goal of the Minang people which has been realized in everyday life. Minangkabau customs uphold nobility and courtesy.

Customs regulate people's lives starting from the family, environment, human relations with humans, both individually and in society, nation and state. As the expression Nan kuriak iyolah kundi, Nan merah iyolah sago, Nan baik iyolah budi, Nan indah Iyolah Baso. This expression shows how Minangkabau custom has instilled character values in society and has become the hallmark of society in Minangkabau. People who do not live according to customary rules are said to be "not baradaik". Minangkabau customs are known for their dynamic and not rigid customs so they can adapt and assimilate with the national culture. The purpose of Minangkabau custom is to form virtuous individuals, cultured humans, and civilized humans. The phrase Hiduik baraka, baukua jo bajangko which means that in carrying out the life of the Minangkabau people, they use their minds and thoughts, have clear plans and an accurate prediction.

Character values have been developed in Minangkabau traditional culture such as 
(1)politeness in relationships (Baso basi malu jo sopan), (2) sensitive to others (Tenggang raso), (3) firm heart (faithful), (4) being fair, impartial, clinging to the truth, (5) frugal, (6) careful, (7) wise, (8) responsive, (9) patient, (10) diligent and (11) humble. Character education has been inherited by traditional stakeholders since ancient times and continues to be preserved until now. local content learning of BAM is a means for schools to instil character values based on Minangkabau culture and customs. Students are introduced to cultural values as early as possible.

\section{The function of the Minang language in learning of BAM}

Minang language is part of the national cultural wealth that must be maintained and preserved. A study conducted by UNESCOappointed Global Education Monitoring shows that $40 \%$ of the world's population accesses education in a language they do not understand. So that the learning objectives are not achieved. Many parties recommend that the initial learning process in the world of education use the everyday language that is mastered by students, in this case, the mother tongue or regional language. The use of the mother tongue is not only able to improve student achievement, but also to protect the language from the threat of extinction.

In learning BAM at elementary schools, the language of instruction in textbooks uses Indonesian. Based on the results of the study, it is known that the effectiveness of the use of the Indonesian language has not been able to instil Minangkabau cultural values in students. Even students do not understand the meaning and implicit meaning of the learning. This needs to be a concern for teachers and stakeholders in schools. The delivery of learning materials using the Minang language is more pleasing to the students. This shows that the mother tongue or regional language is well received by students. The ability of students to express Minang language in BAM learning can develop students' thinking skills, Minang language is also able to be a means of self-expression of students in understanding every meaning of the vocabulary they learn.

The use of Minang language in BAM learning makes it easier for students to understand the material and learning objectives in instilling Minangkabau culture and customs. Language cannot be separated from culture and people's way of thinking because language and culture are always realized overlapping (Ohouiwatun, 2007). Language thought and culture are a series that runs without limits in society. Many expressions in the Minang language that cannot be translated into Indonesian such as the example of contoh "Baladang di ateh kuduak kawan" cannot be read farming on the nape of a friend's neck this will change the meaning and meaning of the expression. The use of regional languages in understanding local culture is very necessary, especially 
about the cultivation of cultural values so that they can be recognized, practised and implemented in everyday life.

Character values that have been fused into Minangkabau culture and customs should be well absorbed by students. Through a good and interesting presentation by the teacher using the Minang language, students can translate the figurative figures, rhymes and proverbs they hear. Using the Minang language in BAM learning at school can increase students' understanding of cultural values and customs that develop in the community, as well as a means of preserving regional languages from extinction.

\section{Implementation of Learning of BAM in instilling character education}

BAM's local content is determined based on the Decree of the Head of Regional Office of the Ministry of Education and Culture No. 011.08.C.1994 dated February 1, 1994, regarding the local content curriculum, one of which is the Minangkabau Natural Culture (BAM). The materials taught are behaviour and attitudes, visiting etiquette, speaking manners, politeness, values contained in traditional ceremonies in Minangkabau, historical heritage, inheritance according to custom, the composition of the kinship system. Each material has basic competencies that must be achieved by students. The meaning of important learning is a mind. Budi is sourced from nature. There are two characteristics of nature, namely the permanent nature, which gives birth to the custom of dead knots; and the changing nature gave birth to the custom with the syntax. These two natural characteristics became the guidelines for Minangkabau customs before Islam entered. Then these two natures are actualized in kato or proverbs. So if we want to learn how the Minangkabau people behave, we have to study the traditional proverbs (Zulkarnaini, 1992).

Learning of BAM means teaching students character, character based on Pancasila and the traditional philosophy of Basandi Syarak, Syarak Basand Kitabullah (Zulkarnaiki, Teachers as the spearhead in delivering material must know culture and customs itself. The teacher's ability to master the material greatly determines the level of student understanding in living each value taught. The teacher must also be a role model for students because what is done repeatedly by the teacher will be imitated by the students. Minangkabau customs have passed down character values in each generation.

One of the education tasks is to create a generation of character. Students can implement all positive teachings and values that develop in the community into habits and rules so that cultural values and customs in Minangkabau can continue to develop and not be lost in the times and eroded by the current globalization. The characteristics of the Minangkabau people who are famous for their 
manners and politeness can be instilled from an early age to all students.

\section{CONCLUSION}

Character education is a system that can give birth to students to become complete human beings, namely good human beings and character. The inculcation of character values must be done from an early age. The integration of character values into local content has created learning that can shape good character, dignity, attitudes and behaviour in students. The philosophy of Minangkabau Custom of adat basandi syarak and syarak basandi Kitabullah are the basis for teaching cultural values. Local content learning is a place for preserving local wisdom in Minangkabau which is rich in character values.

The use of Minang language in delivering learning materials is able to motivate students to recognize, learn and implement it in everyday life. Minang language as mother tongue is a good communication tool to be used in learning local content of BAM because of the power of language, culture and thought into a single unit that lives in the community. Where students grow and develop in it. The Minang language has become a bridge in strengthening the character of students who are taught through local content of Minangkabau Natural Culture in elementary schools

\section{REFERENCES}

[1] Agustina. (2005). "Bahasa Minangkabau: Khasanah BAM yang Terlupakan", dalam Menuju Pembelajaran BAM yang Berkualitas. Padang: Sukabina Offset.

[2] A.Muri Yusuf. (2014). Metodologi Penelitian Kuantitatif, Kualitatif \& Penelitan. Gabungan. Jakarta: Prenadamedia Group. Abdul Halim. 2005. Analisis

[3] Bungin, B. (2007). Penelitian Kualitatif. Prenada Media Group: Jakarta. Saryono. 2010. Metodologi Penelitian Kualitatif dalam Bidang Kesehatan. Yogyakarta: Nuhe Medika.

[4] Departemen Pendidikan dan Kebudayaan. (1997) Penyelenggaraan Pendidikan di Sekolah Dasar. Jakarta: Dirjen Pendidikan Dasar dan Menengah.

[5] Depdikbud, Penerapan Muatan Lokal Kurikulum Sekolah Dasar. Jakarta: Depdikbud 2089: 12-25

[6] Depdikbud (2004), Kamus Besar Bahasa Indonesia, Balai Pustaka, Jakarta

[7] Haromain, Imam Dkk. (2009). Pedoman dan Implementasi Pengembangan Kurikulum Tingkat Satuan Pendidikan MTs. Jawa Timur: Mapemda Kantor Wilayah.

[8] Musfiroh, Tadkiroatun. (2008). Cerdas Melalui Bermain. Jakarta: Grasindo

[9] Naim, Mochtar, (2000) Konflik dan Penyesuaian antara Adat dan Syara' di Minangkabau, makalah disampaikan pada Seminar Reaktualisasi ABS-SBK, ICMI Orwil Sumatera Barat, di Bukittinggi, tanggal 22-23 Januari 2000.

[10] Solahudin, Anas, Irwanto, (2013), Pendidikan Karakter ( Pendidikan berbasis Agama dan Budaya Bangsa) Bandung Pustaka Sakt

[11] Sutopo, HB. (2006), Metode Penelitian Kualitatif, Surakarta: UNS Press.

[12] Suardi, S., Herdiansyah, H., Ramlan, H., \& Mutiara, I. A. (2019). Implementasi Pendidikan Karakter Melalui Mata Pelajaran Pendidikan Kewarganegaraan di SMA Jaya 
Negara Makassar. JED (Journal of Etika Demokrasi), 4(1).

[13] Suardi, S., Megawati, M., \& Kanji, H. (2018). Pendidikan Karakter di Sekolah (Studi Penyimpangan Siswa di Mts Muhammadiyah Tallo). JED (Journal of Etika Demokrasi), 3(1).

[14] Kanji, H., Nursalam, N., Nawir, M., \& Suardi, S. (2019). Evaluasi Integrasi Pendidikan Karakter dalam Pembelajaran Ilmu Pengetahuan Sosial di Sekolah Dasar. JED (Journal of Etika Demokrasi), 4(2).

[15] Zulkarnaini, (1992). Budaya Alam Minang kabau, Usaha Ikhlas Bukittinggi 